\title{
Heats of Formation of Xonotlite, Hillebrandite, and Foshagite
}

\author{
Edwin S. Newman
}

\begin{abstract}
The heats of solution of synthetic xonotlite, $5 \mathrm{CaO} \cdot 5 \mathrm{SiO}_{2} \cdot \mathrm{H}_{2} \mathrm{O}$, hillebrandite, $2 \mathrm{CaO} \cdot \mathrm{SiO}$. $\mathrm{H}_{2} \mathrm{O}$, and a sample of naturally occurring foshagite, $5 \mathrm{CaO} \cdot 3 \mathrm{SiO}_{2} \cdot 3 \mathrm{H}_{2} \mathrm{O}$, were determined in a mixture of nitric and hydrofluoric acids, and their heats of formation from the oxides were calculated to be $-92.6,-34.7$, and -94.6 kilocalories per mole, respectively.
\end{abstract}

\section{Introduction}

The system $\mathrm{CaO}-\mathrm{SiO}_{2}-\mathrm{Al}_{2} \mathrm{O}_{3}-\mathrm{Fe}_{2} \mathrm{O}_{3}-\mathrm{H}_{2} \mathrm{O}$ includes the major constituents of portland and high-alumina cements and the reaction products formed by the hydration of these materials. In connection with the hydrothermal study of parts of that system $[1,2]^{1}$ being conducted at the National Bureau of Standards, the heats of solution of the reaction products and of related minerals are being determined. The heats of solution of these materials and of the reactants from which they theoretically can be formed are measured in appropriate acid solutions in a precision-type calorimeter. The data, combined with literature values for the heats of formation of the reactants [3], permit the calculation of the heats of formation of substances related to the products of hydration of the cements. Appropriate thermochemical equations can be written and the computed heats of reaction can be compared with observed measurements $[4,5]$ for the further elucidation of the hydration reactions occurring between water and hydraulic cements. The present paper gives the results of measurements made with calcium hydroxide and silica gel as reactants and of synthetic hillebrandite, $2 \mathrm{CaO} \cdot \mathrm{SiO}_{2} \cdot \mathrm{H}_{2} \mathrm{O}$, and xonotlite, $5 \mathrm{CaO}$. $5 \mathrm{SiO}_{2} \cdot \mathrm{H}_{2} \mathrm{O}$, as products. In addition, the heat of solution of a sample of the mineral foshagite was determined.

\section{Materials, Apparatus, and Procedure}

\subsection{Materials}

Reagent-quality nitric and hydrofluoric acids, calcium carbonates (low alkali), calcium hydroxide, and precipitated silica (silicic acid) were used. Calcium hydroxide for heat-of-solution measurements was prepared by igniting $\mathrm{CaCO}_{3}$ for 72 hours at $1,000^{\circ} \mathrm{C}$ and treating the resulting $\mathrm{CaO}$ with water [10] at $250^{\circ} \mathrm{C}$ for 2 days. The crystals of $\mathrm{Ca}(\mathrm{OH})_{2}$ obtained were dried, without washing, in a vacuum over magnesium perchlorate and stored in a tightly stoppered bottle in a desiccator over saturated $\mathrm{KOH}$ until used. The ignition loss of this material was

\footnotetext{
1 Figures in bracketsindicate the literature references at the end of this paper.
}

$24.30_{7}$ percent, to be compared with $24.31_{4}$ percent calculated from the formula.

The reagent-quality silicic acid used for the heatof-solution measurements had a water content of 12.82 percent and a nonvolatile residue of 0.023 percent when treated with hydrofluoric acid. The silica was kept over saturated $\mathrm{MgCl}_{2} \cdot 6 \mathrm{H}_{2} \mathrm{O}$ solution for 2 weeks before its heat of solution was determined. At that time the water content was about 20 percent. According to Mulert [9], whose data were used in calculating the heat of formation of $\mathrm{SiO}_{2}$. aq given in reference [3], the heat of solution of hydrated silicic acid per mole of silica does not change with further increase in water content.

Xonotlite was prepared from $\mathrm{Ca}(\mathrm{OH})_{2}$ and silicic acid. These materials were mixed together in a $\mathrm{CaO} / \mathrm{SiO}_{2}$ ratio of 1.000 by tumbling for several hours in a glass bottle with a few wooden balls. Twenty grams of this mixture was prepared and heated overnight at $950^{\circ} \mathrm{C}$ in a platinum dish, cooled in a desiccator and flooded with freshly boiled distilled water. The dish was transferred to a small bomb and heated at $250^{\circ} \mathrm{C}$. The flooding and transfer of the dish and the closure of the bomb were made as rapidly as possible to minimize exposure to $\mathrm{CO}_{2}$ in the air. The bomb was opened at the end of 2 weeks and the hardened mass of surface-dry material ground quickly to pass through a No. 28 sieve and dried for 2 hours in a vacuum over $\mathrm{Mg}$ $\left(\mathrm{ClO}_{4}\right)_{2}$.

Three samples of synthetic hillebrandite, $\mathrm{C}_{2} \mathrm{SH}(\mathrm{B})$ [11], were prepared in a similar manner by heating the material with water at $242^{\circ}, 178^{\circ}$, and $152^{\circ} \mathrm{C}$ for 7,16 , and 14 days, respectively. These samples also, as well as selected fibers of foshagite from Crestmore, Calif., were crushed rapidly to pass a No. 28 sieve and dried.

The samples were analyzed for $\mathrm{SiO}_{2}, \mathrm{Fe}_{2} \mathrm{O}_{3}+\mathrm{Al}_{2} \mathrm{O}_{3}$, $\mathrm{CaO}$, and $\mathrm{MgO}$ by the methods described in Federal Specification SS-C-158c. Loss on ignition was determined by heating $1-\mathrm{g}$ samples at $1,200^{\circ} \mathrm{C}$. The $\mathrm{CO}_{2}$ content was determined on $2-\mathrm{g}$ samples, and the water content was taken as the difference between the loss on ignition and the $\mathrm{CO}_{2}$ content. X-ray patterns, obtained by using a recording X-ray diffractometer with copper radiation $1.5418 \mathrm{~A}$, were used to confirm the identity of the samples by comparison with published patterns [12]. 
TAPLE 1. Analyses of calorimeter samples

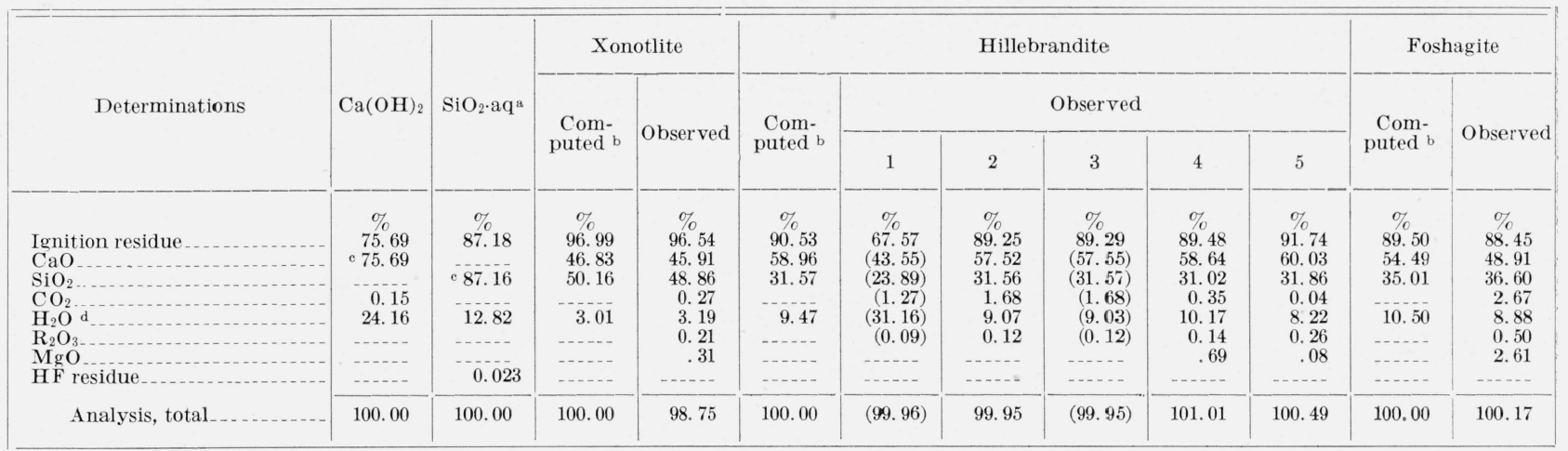

a As taken from stock bottle. b Computed from formula $5 \mathrm{CaO} \cdot 5 \mathrm{SiO}_{2} \cdot \mathrm{H}_{2} \mathrm{O}$ for xonotlite; $2 \mathrm{CaO} \cdot \mathrm{SiO}_{2} \cdot \mathrm{H}_{2} \mathrm{O}$ for hillebrandite; and $5 \mathrm{CaO} \cdot 3 \mathrm{SiO} \cdot 3 \mathrm{H}_{2} \mathrm{O}$ for foshagite By difference. d Loss on ignition minus $\mathrm{CO}_{2}$.

The results of the chemical analyses are given in table 1. For easy comparison there are also included the analyses of the silicates computed from the formulas. The first sample of hillebrandite, prepared considerably before the others, was found to contain excess moisture. It was dried further and analyzed and its heat of solution again measured. Subsequently, its ignition loss and heat of solution were redetermined. This material appears as hillebrandite samples 1, 2, and 3 in the tables. Figures in parentheses in table 1 represent its analysis as sample 2 computed to its moisture content as samples 1 and 3.

The agreement between observed and calculated compositions was satisfactory for the synthetic preparations. The foshagite, however, had undergone considerable alteration. The sample consisted of selected fibers, taken from a $50-\mathrm{g}$ fibrous mass. Perhaps 30 percent of the sample was of somewhat lower index than reported for foshagite, and some brownish material was present.

\subsection{Apparatus and Procedure}

The calorimeter has been adequately described elsewhere $[6,7]$. It was operated so that the final temperature was always within a few hundredths of a degree of $25^{\circ} \mathrm{C}$. Since the heat capacities of the reactants were used in computations, the isothermal heats of solution at $25^{\circ} \mathrm{C}$ were obtained. The energy equivalent of the calorimeter was determined electrically, using the defined calorie of 4.1840 absolute joules. The heat capacities of the samples, introduced at room temperature, were taken as 0.2 cal/deg-g. The calculated correction for the sensible heat introduced with a sample rarely amounted to as much as $0.05 \mathrm{cal} / \mathrm{g}$.

The acid charge used had a total weight of $600.0 \mathrm{~g}$, of which $11.0 \mathrm{ml}(12.6 \mathrm{~g})$ was 48 percent $\mathrm{HF}$, the remainder being $2.000 \mathrm{NHNO}_{3}\left(\right.$ at $25^{\circ} \mathrm{C}$ ). Its composition therefore [8] was $0.30 \mathrm{HF}, 1.10 \mathrm{HNO}_{3}$, $29.10 \mathrm{H}_{2} \mathrm{O}$. The sample weight was generally $1 \mathrm{~g}$. When silica gel containing 20 percent of $\mathrm{H}_{2} \mathrm{O}$ was being dissolved, the $\mathrm{HF} / \mathrm{SiO}_{2}$ molar ratio was 22.8 , well in excess of the value of six, beyond which the heat of solution of silica in hydrofluoric acid becomes constant [9]. It was observed that $3-\mathrm{g}$ samples of portland cement containing about $1.8 \mathrm{~g}$ of combined $\mathrm{CaO}$ could be dissolved without precipitation of $\mathrm{CaF}_{2}$, but that when dissolving $\mathrm{Ca}(\mathrm{OH})_{2}$ alone the sample weight had to be reduced to $0.7 \mathrm{~g}$. Under these conditions there was no weighable or visible precipitate of $\mathrm{CaF}_{2}$, but with $0.8-\mathrm{g}$ samples of $\mathrm{Ca}(\mathrm{OH})_{2}$ a faintly visible haze remained in the solution after filtration had removed $0.6 \mathrm{mg}$ of precipitated $\mathrm{CaF}_{2}$. Consequently approximately $0.7-\mathrm{g}$ samples of $\mathrm{Ca}(\mathrm{OH})_{2}$ were used to determine the heat of solution of that substance. It was assumed that the heat of the dilution effects caused by the differences in the concentrations of the final solutions were negligible, and no corrections were made.

\section{Results and Discussion}

The observed heats of solution are given in table 2 . The amount of $\mathrm{CaCO}_{3}$ equivalent to the $\mathrm{CO}_{2}$ was calculated for each sample, and its heat of solution, $86 \mathrm{cal} / \mathrm{g}$ [4], deducted from the observed heat of solution. The total $\mathrm{CaO}$ was reduced by an equivalent amount. The heats of solution of the samples per mole of $\mathrm{SiO}_{2}, A$, were calculated by the formula $A=a(100 \times 60.06 / P)$, where $a$ is the observed heat of solution of the sample, corrected for $\mathrm{CO}_{2}, P$ is the percentage of silica in the sample as given in table 1 , and 60.06 is taken as the molecular weight of $\mathrm{SiO}_{2}$. These calculated values are given in table 3. Empirical formulas, calculated from table 1 corrected for $\mathrm{CO}_{2}$, are also given in table 3 . In making the foregoing calculations for the foshagite, an equivalent amount of $\mathrm{CaO}$ was substituted for the $\mathrm{MgO}$ found by analysis.

The heat of solution of $\mathrm{C} / \mathrm{S}^{2}$ moles of $\mathrm{Ca}(\mathrm{OH})_{2}$ was calculated for each sample and added to the heat of solution of 1 mole of $\mathrm{SiO}_{2}, 0.828 \mathrm{H}_{2} \mathrm{O}$ to determine the heats of solution of the reactants from which the

2 Conventionally, $\mathrm{CaO}, \mathrm{SiO}_{2}$, and $\mathrm{H}_{2} \mathrm{O}$ are represented by the letters $\mathrm{C}, \mathrm{S}$, and $\mathrm{H}$, respectively, $2 \mathrm{CaO} \cdot \mathrm{SiO}_{2} \cdot \mathrm{H}_{2} \mathrm{O}$ being represented by the formula $\mathrm{C}_{2} \mathrm{SH}$. 
TAPLE 2. Results of calorimetric measurements

\begin{tabular}{|c|c|c|c|c|c|c|c|c|c|}
\hline \multirow{3}{*}{$\begin{array}{l}\text { Calorimeter } \\
\text { energy } \\
\text { equivalent }\end{array}$} & \multicolumn{9}{|c|}{ Heats a of solution } \\
\hline & \multirow{2}{*}{$\mathrm{Ca}(\mathrm{OH})_{2} \mathrm{~b}$} & \multirow{2}{*}{$\mathrm{SiO}_{2} \cdot \mathrm{aq}^{\mathrm{c}}$} & \multirow{2}{*}{ Xonotlite } & \multicolumn{5}{|c|}{ Hillebrandite } & \multirow{2}{*}{$\begin{array}{l}\text { Natural } \\
\text { foshagite }\end{array}$} \\
\hline & & & & 1 & 2 & 3 & 4 & 5 & \\
\hline $\begin{array}{c}\text { cal/ohm d } \\
5723.2 \\
5720.2 \\
5716.9 \\
5718.8 \\
5717.0 \\
-\end{array}$ & $\begin{array}{c}\mathrm{call} / \mathrm{g} \\
429.97 \\
429.69 \\
429.32 \\
429.31 \\
429.26 \\
430.24\end{array}$ & $\begin{array}{c}c a l / g \\
468.72 \\
468.64 \\
466.81 \\
470.86 \\
470.00 \\
468.51\end{array}$ & $\begin{array}{c}c a l / g \\
490.87 \\
490.92 \\
490.67 \\
491.66 \\
490.16 \\
490.42\end{array}$ & $\begin{aligned} & c a l / g \\
& \text { e } 354.4 \\
& \text { e } 351.0 \\
&-.- \\
&-\end{aligned}$ & $\begin{array}{c}\text { cal } / g \\
462.40 \\
461.57 \\
461.79 \\
-.- \\
-\end{array}$ & $\begin{array}{c}c a l / g \\
460.62 \\
459.00 \\
459.53 \\
459.46 \\
459.96 \\
459.36\end{array}$ & $\begin{array}{c}c a l / g \\
470.47 \\
470.32 \\
469.94 \\
469.14 \\
468.91 \\
469.29\end{array}$ & $\begin{array}{c}c a l / g \\
490.39 \\
\mathbf{4} 89.19 \\
\mathbf{4} 88.47 \\
\mathbf{4} 88.51 \\
\mathbf{4 8 8} .48 \\
\mathbf{4 8 9} .39\end{array}$ & $\begin{array}{c}c a l / g \\
437.94 \\
438.67 \\
438.66 \\
439.31 \\
438.67 \\
437.27\end{array}$ \\
\hline A verage 5719.2 & 429.63 & 468.92 & 490. 78 & 352.7 & 461.92 & 459. 66 & 469.68 & 489. 07 & 438.42 \\
\hline $\begin{array}{l}\text { Std. dev. } \\
\quad \text { of avg }{ }_{-} \quad 1.2\end{array}$ & 0.17 & 0.57 & 0.21 & 1. 7 & 0.25 & 0.23 & 0.27 & 0.31 & 0.29 \\
\hline
\end{tabular}

a 1 -g sample in $600-\mathrm{g} \mathrm{HF}+\mathrm{HNO}_{3}$ mixture $\left(0.30 \mathrm{HF}, 1.10 \mathrm{HNO}_{3}, 29.10 \mathrm{H}_{2} \mathrm{O}\right)$.

b $0.7-9$ sample in $600-\mathrm{g} \mathrm{HF}+\mathrm{HNO}_{3}$ mixture $0.30 \mathrm{HF} 1.10 \mathrm{HNO}, 29.10 \mathrm{H}$

c Sample stored over saturated solution of $\mathrm{MgCl}_{2} \cdot 6 \mathrm{H}_{2} \mathrm{O}$. Relative humidity 33 percent. Ignition residue of sample 80.11 percent, equivalent to 80.09 percent of $\mathrm{SiO}_{2}, 0.02$ percent of $\mathrm{HF}$ residue, 19.89 percent of $\mathrm{H}_{2} \mathrm{O} . \mathrm{H} / \mathrm{S}=0.828$.

$\mathrm{d} \Delta R / \Delta T$ is 0.1010 at $25^{\circ} \mathrm{C} ; 5719.2 \mathrm{cal} / \mathrm{ohm}$ is approximately $577.6 \mathrm{cal} / \mathrm{deg}$

e 1 -g sample in $425-\mathrm{g} \mathrm{HF}+\mathrm{HNO}_{3}$ mixture $\left(0.22 \mathrm{HF}, 0.78 \mathrm{HNO}_{3}, 20.61 \mathrm{H}_{2} \mathrm{O}\right)$ in vacuum-flask calorimeter.

i Standard deviation of a verage $=\sqrt{\left[\Sigma x^{2}-(\Sigma x)^{2} / n\right] / n(n-1)}$.

TAPle 3. Heat of reaction of $\mathrm{Ca}(\mathrm{OH})_{2}$ and $\mathrm{SiO}_{2} \cdot 0.83 \mathrm{H}_{2} \mathrm{O}$

\begin{tabular}{|c|c|c|c|c|}
\hline \multirow{2}{*}{ Sample } & \multirow{2}{*}{ Empirical Formula a } & \multicolumn{2}{|c|}{ Heat of solution b } & \multirow{2}{*}{$\begin{array}{c}\text { Heat of } \\
\text { reaction, } \\
\Delta H\end{array}$} \\
\hline & & Products & Reactants & \\
\hline $\mathrm{Ca}(\mathrm{OH})_{2} \ldots$. & $1.00 \mathrm{CaO} \cdot 1.00 \mathrm{H}_{2} \mathrm{O}$ & kcal/mole & $\begin{array}{c}\mathrm{kcal} / \mathrm{mole} \\
{ }^{\circ} 31.88\end{array}$ & $\mathrm{kcal} / \mathrm{mole}$ \\
\hline $\mathrm{SiO}_{2} \cdot \mathrm{aq}$ & $1.00 \mathrm{SiO}_{2} \cdot 0.83 \mathrm{H}_{2} \mathrm{O}$ & - & 35.16 &.- \\
\hline Xonotlite & $0.98 \mathrm{CaO} \cdot 1.00 \mathrm{SiO}_{2} \cdot 0.21 \mathrm{H}_{2} \mathrm{O}$ & 59.06 & 66.40 & -7.34 \\
\hline \multirow[t]{2}{*}{$\begin{array}{c}\text { Hillebrandite: } \\
1 \\
2 \\
4 \\
5\end{array}$} & $\begin{array}{l}1.88 \mathrm{CaO} \cdot 1.00 \mathrm{SiO}_{2} \cdot 4.35 \mathrm{H}_{2} \mathrm{O} \\
1.88 \mathrm{CaO} \cdot 1.00 \mathrm{SiO}_{2} \cdot 0.96 \mathrm{H}_{2} \mathrm{O} \\
1.88 \mathrm{CaO} \cdot 1.00 \mathrm{SiO}_{2} \cdot 0.96 \mathrm{H}_{2} \mathrm{O} \\
2.01 \mathrm{CaO} \cdot 1.00 \mathrm{SiO}_{2} \cdot 1.09 \mathrm{H}_{2} \mathrm{O} \\
2.02 \mathrm{CaO} \cdot 1.00 \mathrm{SiO}_{2} \cdot 0.86 \mathrm{H}_{2} \mathrm{O}\end{array}$ & $\begin{array}{l}88.04 \\
87.31 \\
86.82 \\
90.80 \\
92.18\end{array}$ & $\begin{array}{l}95.09 \\
95.09 \\
95.09 \\
99.24 \\
99.56\end{array}$ & $\begin{array}{l}-7.05 \\
-7.78 \\
-8.27 \\
-8.44 \\
-7.38\end{array}$ \\
\hline & & \multicolumn{2}{|c|}{ Weighted a verage .......... } & -7.91 \\
\hline Foshagite.... & $1.44 \mathrm{CaO} \cdot 1.00 \mathrm{SiO}_{2} \cdot 0.81 \mathrm{H}_{2} \mathrm{O} \mathrm{d}$ & 71.13 & 81.06 & -9.93 \\
\hline
\end{tabular}

a Calculated from analysis, corrected for $\mathrm{CaCO}_{3}$.

Corrected for $\mathrm{CaCO}_{3}$.

- Kilocalorie per mole of $\mathrm{Ca}(\mathrm{OH})_{2}$.

d 2.61 percent of $\mathrm{MgO}$ assumed equivalent to 3.63 percent of $\mathrm{CaO}$.

samples can be considered to be formed by the equation

$$
\begin{gathered}
(\mathrm{C} / \mathrm{S}) \mathrm{Ca}(\mathrm{OH})_{2}+\mathrm{SiO}_{2}, 0.828 \mathrm{H}_{2} \mathrm{O} \rightarrow(\mathrm{C} / \mathrm{S}) \mathrm{CaO} \cdot \mathrm{SiO}_{2} . \\
(\mathrm{H} / \mathrm{S}) \mathrm{H}_{2} \mathrm{O}+(\mathrm{C} / \mathrm{S}+0.828-\mathrm{H} / \mathrm{S}) \mathrm{H}_{2} \mathrm{O}+\Delta H .
\end{gathered}
$$

The sum of the heats of solution of the reactants minus the heats of solution of the products is equal to the heat of the reaction. The partial molal heat content of the water in $\mathrm{HNO}_{3}, 26.3 \mathrm{H}_{2} \mathrm{O}$ is approximately $0.002 \mathrm{kcal} / \mathrm{mole}$; in $\mathrm{HF}, 100 \mathrm{H}_{2} \mathrm{O}$ it is about $0.0004 \mathrm{kcal} / \mathrm{mole}$ [13]. These quantities, which represent approximately the heat of solution of the water produced in the reaction, are negligible.

In table 3 are given the calculated heats of reaction of $\mathrm{Ca}(\mathrm{OH})_{2}$ and silica gel to form the samples used in this investigation. These values are given on the basis of 1 mole of silica. The hydrated calcium silicates as occurring in nature or as prepared in the laboratory have variable composition. On the assumption that the heats of reaction per mole of silica would be the same for the substances with formulas generally accepted [11], the heats of formation of $5 \mathrm{CaO} \cdot 5 \mathrm{SiO}_{2} \cdot \mathrm{H}_{2} \mathrm{O}, 2 \mathrm{CaO} \cdot \mathrm{SiO}_{2} \cdot \mathrm{H}_{2} \mathrm{O}$, and $5 \mathrm{CaO}$. $3 \mathrm{SiO}_{2} \cdot 3 \mathrm{H}_{2} \mathrm{O}$ from lime, quartz, and liquid water were calculated. To perform these calculations, the heat of formation [3] of $\mathrm{Ca}(\mathrm{OH})_{2}, \mathrm{SiO}_{2}$ aq, and liquid water were substituted in eq (1) together with the heats of reaction as determined from the heat-of-solution measurements. The heats of formation of the hydrated calcium silicates were then obtained as the sum of the heats of formation of the reactants plus the heat of the reaction minus the heat of formation 
of the water appearing on the right side of eq (1). Using the heats of formation thus obtained for the silicates, thermochemical equations were written for the reactions forming $5 \mathrm{CaO} \cdot 5 \mathrm{SiO}_{2} \cdot \mathrm{H}_{2} \mathrm{O}, 2 \mathrm{CaO} \cdot \mathrm{SiO}_{2}$. $\mathrm{H}_{2} \mathrm{O}$, and $5 \mathrm{CaO} \cdot 3 \mathrm{SiO}_{2} \cdot 3 \mathrm{H}_{2} \mathrm{O}$ from lime, quartz, and liquid water, and the heats of the reactions calculated in the usual manner [3]. The values obtained are given in table 4.

TABLE 4. Heats of formation of hydrated calcium silicates

\begin{tabular}{|c|c|c|c|}
\hline Name & $\begin{array}{l}\text { Bogue } \\
\text { designa- } \\
\text { tion }[11]\end{array}$ & Formula a & $\begin{array}{l}\text { Heat of formation, } \Delta H, \\
\text { from } \\
\mathrm{CaO} \text { (c), } \mathrm{SiO}_{2}(\mathrm{c}, \text { quartz) } \\
\text { and } \mathrm{H}_{2} \mathrm{O}^{\prime}(1)\end{array}$ \\
\hline $\begin{array}{l}\text { Xonotlite } \\
\text { Hillebrandite } \\
\text { Foshagite..... }\end{array}$ & $\begin{array}{l}\mathrm{C}_{5} \mathrm{~S}_{5} \mathrm{H} \\
\mathrm{C}_{2} \mathrm{SH}_{(\mathrm{B})} \\
\mathrm{C}_{5} \mathrm{~S}_{3} \mathrm{H}_{3}\end{array}$ & $\begin{array}{l}5 \mathrm{CaO} \cdot 5 \mathrm{SiO}_{2} \cdot \mathrm{H}_{2} \mathrm{O} \\
2 \mathrm{CaO} \cdot \mathrm{SiO}_{2} \cdot \mathrm{H}_{2} \mathrm{O} \\
5 \mathrm{CaO} \cdot 3 \mathrm{SiO}_{2} \cdot 3 \mathrm{H}_{2} \mathrm{O}\end{array}$ & $\begin{array}{l}\text { kcal/mole } \\
-92.6 \\
-34.7 \pm 0.9 \\
-94.6\end{array}$ \\
\hline
\end{tabular}

a The heats of formation from the oxides are calculated on the basis of these formulas. The heats of reaction of the reactants $\mathrm{Ca}(\mathrm{OH})_{2}$ and $\mathrm{SiO}_{2} \cdot \mathrm{aq}$ to form the individual compounds was taken from table 3 and the heats of formation of the reactants from the oxides calculated from NBS Circular 500 [3].

\section{Summary}

The heats of solution of synthetic xonotlite, hillebrandite, and natural foshagite have been determined in a mixture of nitric and hydrofluoric acids, and their heats of formation from the oxides have been calculated to be $-92.6,-34.7$, and -94.6 $\mathrm{kcal} /$ mole, respectively.

\section{References}

[1] R. B. Peppler and L. S. Wells, J. Research NBS 52, 75 (1954) RP2476.

[2] R. B. Peppler, J. Research NBS 54, 205 (1955) RP2582.

[3] Selected values of chemical thermodynamic properties, NBS Circular 500 (U. S. Government Printing Office, 1952).

[4] S. Brunauer, G. C. Hayes, and W. E. Hass, J. Phys. Chem. 58, 279 (1954).

[5] C. Brisi, Ricerca sci. [7] 24, 1436 (1954).

[6] E. S. Newman and L. S. Wells, J. Research NBS 20, 825 (1938) RP1107.

[7] E. S. Newman, J. Research NBS 54, 347 (1955) R P2597.

[8] International Critical Tables, National Research Council (McGraw-Hill Book Co., Inc., New York, N. Y., 1933).

[9] O. Mulert, Z. anorg. u. allgem. Chem. 75, 198 (1912).

[10] T. Thorvaldson and W. G. Brown, J. Am. Chem. Soc. 52, $80(1930)$

[11] R. H. Bogue, Mag. of Concrete Research 14, 87 (Dec. $1953)$

[12] H. F. McMurdie and E. P. Flint, J. Research NBS 31, 225 (1943) RP1560.

[13] L. S. Wells and K. Taylor, J. Research NBS 19, 215 (1937) RP1022.

Washington, February 24, 1956. 